\title{
Expression of Aintegumenta-like Gene Related to Embryogenic Competence in Coconut Confirmed by 454-pyrosequencing Transcriptome Analysis
}

\author{
H D D Bandupriya*
}

\begin{abstract}
A member of the Aintegumenta sub-family of Apetala gene family encoding two APETALA2 (AP2) domains was isolated and termed as Cocos nucifera Aintegumenta like gene (CnANT). The deduced amino acid sequence of the conserved domains shared a high similarity with AintegumentaLike (ANT like) genes in Arabidopsis thaliana, Elaeis guineensis, Oryza sativa. Comparison of transcriptomes in different tissues revealed that CnANT transcripts were high in mature zygotic embryo (12 months after pollination; 12ME). Quantitative RT-PCR results confirmed the higher CnANT transcript accumulation in mature zygotic embryos while transcripts were rarely detected in vegetative tissues such as leaf. The expression data and global transcriptome data were therefore consistent across the embryo maturity stage and showed that CnANT could play a role in embryogenesis.
\end{abstract}

Keywords: coconut, zygotic embryo, Aintegumenta, transcriptome.

\section{Introduction}

Coconut (Cocos nucifera L.) is a perennial cross-pollinated plant that is cultivated mainly for edible oil in the tropical and sub-tropical regions. Despite its economic importance, coconut production has not been increased as we see in other oil crops. Production of high quality superior palms in large scale is a prerequisite for the development of coconut industry. Achieving this target using seeds as the planting material is impossible. Its propagation by tissue culture was first reported in 1983 (Branton and Blake 1983). Since then cloning of coconut via somatic embryogenesis has been addressed by several researchers in different research groups (Fernando and Gamage 2000; Hornung 1995; Karunaratne and Periyapperuma 1989; Perera et al. 2008; Perera et al. 2007; Verdeil et al. 1994). However, its highly recalcitrant behavior for in vitro conditions limits the success of coconut micropropagation (George and Sherrington 1984). Therefore, understanding of the molecular basis of coconut tissue culture would provide necessary information needed for the improvement of the in vitro propagation protocol.

Members of the sub family Aintegumenta-Like (AIL) of the Apetala2/Ethylene-responsive element binding protein (AP2/EREBP) family play an important role during the transition from vegetative to embryogenic growth (Banno et al. 2001; Boutilier et al. 2002). BABY BOOM (BBM) is one of such genes known for its role in cell proliferation and morphogenesis during embryogenesis (Boutilier et al. 2002). These genes are expressed in dividing tissues where they have central roles in

*Senior Research Officer, Tissue Culture Division, Coconut Research Institute, Lunuwila, Sri Lanka.

Correspondence author: Email: dbandupriya@yahoo.com

Tel: +94312262003; $\quad$ Fax: +94312257391 
developmental processes such as embryogenesis. Overexpression of the AIL genes induces somatic embryogenesis and ectopic organ formation (Boutilier et al. 2002; Tsuwamoto et al. 2010). The characterization and functional analysis of markers such as AIL for somatic embryogenesis offer the possibility of determining the embryogenic potential of coconut in culture long before any morphological changes have taken place. Since zygotic embryo development always mimic the somatic embryogenesis, most studies on gene isolation have been carried out initially using zygotic embryo tissues (Cairney and Pullman 2007; Palovaara et al. 2010) .

Next generation sequencing (NGS) technologies enable scientists to analyze the complete transcriptome at a minimal cost. Roche 454 Genome Sequencer (GS) FLX platform is widely used for de novo sequencing and EST analyses in non-model plants (Barakat et al. 2009; Graham et al. 2010; Li et al. 2010; Luo et al. 2010; Wang et al. 2009; Novaes et al. 2008; Alagna et al. 2009) and is an ideal way to discover genes and markers, quantify transcripts and discover small RNA (Morozova et al. 2009; Brautigam and Gowik 2010). In the present study Aintegumeta like gene was identified in coconut zygotic embryos and expression was checked in four different plant tissues. The occurrence of this Aintegumenta like gene was further identified in a separate transcriptome analysis during AP2/EREBP family gene mining.

\section{Materials and methods}

\section{Plant Material}

Seeds were from variety 'Sri Lanka Tall' and were harvested from bunches at 12-month maturity stage (given that 0 is the most mature unopened inflorescence embryos were used to extract RNA for gene isolation. Four different tissue types from the variety 'Sri Lanka Tall' namely, immature embryo at the age of nine months after pollination (9ME), mature embryo at the age of 12 months after pollination (12ME), a microspore derived embryo (MDE) (Perera $e t$ al. 2008) and developing leaves from an 8month old in vitro germinated coconut plantlet were used for the cDNA library construction for the 454 sequence analysis.

\section{RNA Extraction}

Total RNA from each tissue sample was extracted using the RNeasy® Plant Kit (Qiagen) according to the manufacturer's instructions. DNA contaminations were eliminated by treating with DNase I (Qiagen, UK) according to the manufacturer's instructions. The amount of RNA was quantified using a NanoDrop® ND1000 Spectrophotometer and integrity was analyzed by $1 \%$ agarose gel electrophoresis.

\section{Cloning of coconut ANT-like cDNA}

Primers [2 F (5-TCT ATC TAC CGC GGC GTC- 3') and 4R (5-ACA AAC TCC TGT CGT GTC A-3'), 4 F (5-TGA CAC GAC AGG AGT TTG T-3') and 5R2 (5-ATT CCA TTC CAA AGA TGG G-3')] were designed to amplify the coconut ANT-like cDNA sequence on the basis of the most conserved nucleotide sequences of rice (Accession NM 001060643) and oil palm (Accession AY691196) Aintegumenta-like genes. Approximately $1 \mu \mathrm{g}$ of total RNA was used to synthesize first strand cDNA using SensiMix 2 step kit (Quantace) according to the manufacturer's instructions. PCR was performed using $1 \mu \mathrm{L}$ of cDNA in the presence of primers at $0.3 \mu \mathrm{M}$ concentration. Each PCR reaction was carried out in a $25 \mu \mathrm{L}$ reaction volume containing $12.5 \mu \mathrm{L} 2 \mathrm{X}$ Biomix (Bioline). After an initial 2 min denaturation step at $94^{\circ} \mathrm{C}, 30$ cycles were run, each with $30 \mathrm{~s}$ of denaturation at $94^{\circ} \mathrm{C}$, followed by $30 \mathrm{~s}$ of annealing at $57^{\circ} \mathrm{C}$ and $45 \mathrm{~s}$ of extension at $72^{\circ} \mathrm{C}$. The final elongation cycle was at $72^{\circ} \mathrm{C}$ for $7 \mathrm{~min}$. Purified PCR products were subjected to BigDye terminator cycle sequencing reaction and sequenced at the Bio-Centre, University of Reading. From these amplifications $1031 \mathrm{bp}$ length fragment was obtained. Flanking sequence determination of 5 ' and 3 ' ends was carried out by the RACE method using the GeneRacer kit (Invitrogen) using the primers provided by the kit (GeneRacer 5 primer 5-CGA CTG GAG CAC GAG GAC ACT GA-3, GeneRacer 3'primer 5'-GCT GTC AAC GAT ACG CTA CGT AAC G-3, '5' nested primer 5' 
GGA CAC TGA CAT GGA CTG AAG TAG AAA-3', 3'nested primer 5'-CGC TAC GTA ACG GCA TGA CAG TG-3'and gene specific primers 4R, 4F, 3R (5'-CGC CTT CTC CTC CTT ATC-3'), ANTF (5'-AAC TGG ATT ATG CAT GAT GA-3)'according to the manufacturer's protocol.

\section{Real-time RT-PCR expression analysis}

Two gene-specific primers; ANTF1: (5'CGG TCT CTT CTC CTC TGG TG-3') and ANTR: (5'-TCG TAA TTC CCT CCA AAT GC-3') were designed based on the coding region of the CnANT gene to amplify a $180 \mathrm{bp}$ region. The coconut elongation factor gene was used as the internal control gene (Morcillo et al. 2007; Olsvik et al. 2005). cDNA from the four tissue types 9ME, 12ME, MDE and LEAF were used for real-time RT-PCR analysis using SYBR premix Ex taqTM (Takara). Experiments were conducted with two biological samples, and the real-time qPCR reactions were performed in triplicate using the CAS-1200 liquid handling system, version 4.7.979 (Corbett Robotics). The real-time RT-PCR was performed on a RotorGene 6000 real-time cycler (software 1.7, Corbett Research). The amplification parameters were one cycle at $95{ }^{\circ} \mathrm{C}$ for $1 \mathrm{~min}, 39$ cycles of $95^{\circ} \mathrm{C}$ for $10 \mathrm{~s}, 60^{\circ} \mathrm{C}$ for $20 \mathrm{~s}$, and $72^{\circ} \mathrm{C}$ for $8 \mathrm{~s}$. The relative expression level in different tissues was calculated by the standard curve method.

\section{cDNA synthesis and 454 pyrosequencing}

The first-strand cDNA was produced from $0.3 \mu l g$ of total RNA. A modified SMART-Sfi1A oligonucleotide (5' - AAG CAG TGG TAT CAA CGC AGA GTG GCC ATT ACG GCCrGrGrG3') was used in combination with the CDS-Sfi1B primer (5'- AAG CAG TGG TAT CAA CGC AGA GTG GCC GAG GCG GCC d (T) 20-3') to synthesize the first strand cDNA in the presence of PowerScript Reverse Trascriptase (BD Biosciences Clontech,UK). For doublestranded cDNA (ds cDNA) synthesis, the cDNA was diluted and amplified using PCR Advantage II polymerase (BD Biosciences Clontech,UK) in the presence of SMART PCR primer ( 5'-AAG CAG TGG TAT CAA CGC AGA GT- 3'). The following the thermal profile: $1 \mathrm{~min}$ at $95^{\circ} \mathrm{C}$ followed by 25 cycles of $95^{\circ} \mathrm{C}$ for $7 \mathrm{~s}, 65^{\circ} \mathrm{C}$ for
$20 \mathrm{~s}$, and $72^{\circ} \mathrm{C}$ for 3 min was used for the amplification. Five micro liters of PCR product was electrophoresed in a $1 \%$ agarose gel to determine the amplification efficiency. The amplified cDNA PCR product was purified using QIAquick PCR Purification Kit (QIAGEN, $\mathrm{CA}$ ), concentrated by ethanol precipitation and adjusted to a final concentration of $50 \mathrm{ng}^{-1}$. A total yield of $3 \mu \mathrm{g}$ of $\mathrm{cDNA}$ was prepared for each tissue type by conducting several long distance PCR reactions. DNA sequencing of four libraries was performed at Centre for Genomic Research, University of Liverpool using a 454GS FLX Genome Sequencer and the sequence data processing was performed with the GS FLX software v2.0.01. Sequences in each library were subjected to a BLAST search against the nonredundant protein database using BLASTX with an e value cut-off of 1E-6. AP2 family proteins were identified in each library based on the BLASTX search.

\section{Results and discussion}

\section{Cloning of full length cDNA homologue of Aintegumenta-like gene}

A partial sequence (1029 bp) of Aintegumenta-like homologue gene was obtained by PCR using primer pairs $2 \mathrm{~F}, 4 \mathrm{R}$ and 4F, 5R2. Amplification products of 5'-RACE and 3'-RACE generated the full length cDNA sequence that was $1782 \mathrm{bp}$ in length. We named it as Cocos nucifera L. Aintegumenta (CnANT) gene. This contained a 1425 bp open reading frame (ORF), 62 nucleotides at the 5'untranslated region (UTR) and 305 nucleotides at the 3' UTR including 26 adenines from the polyA tail. The ORF encoded a putative peptide of a 474 amino acids (Figure 1).

Sequence database searches revealed that the deduced polypeptide sequence of CnANT shows similarity to AP2/EREBP family proteins. This putative CnANT protein sequence contains two AP2 domains from protein residues 128 to 204 in repeat one and residues 230 to 298 in repeat two and a conserved linker region from residues 205 to 229 (Figure 1). Within the CnANT polypeptide sequence the highly conserved YRG elements encoded by amino acid residues from 128 to 149 and 230 to 251 were 
AGCGTTCAAATCAAAACCTTCT TTCTCAACITGITATTCCGGGGATACCCIGGCAGCGCC atggacatggacgct tcacacagctggctcgcct tctcgetatccaaccaccagccctac $\begin{array}{llllllllllllllllllll}M & D & M & D & A & S & H & S & W & L & A & F & S & L & S & N & H & Q & P & Y\end{array}$ cttctcgaggctctg tcctccgcccatccaca tggtggggtggaga tgacggeggaggag $\begin{array}{llllllllllllllllllll}L & L & E & A & L & S & S & A & H & P & H & G & G & V & E & M & I & A & E & E\end{array}$ cggggaggatcggcggaagtggcggcgctggcgg tgatggggccgaagctggaggact $c$ $\begin{array}{llllllllllllllllllll}R & G & G & S & A & E & V & A & A & L & A & V & M & G & P & K & L & E & D & F\end{array}$

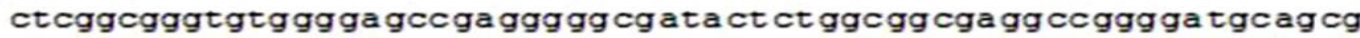
$\begin{array}{llllllllllllllllllll}I & G & G & C & G & E & P & R & G & R & Y & S & G & G & E & A & G & D & A & A\end{array}$ gggatctacgactctgaactgaagcacatcgccgccgggtacctgcaggggctaccgccg $\begin{array}{llllllllllllllllllll}G & I & Y & D & S & E & L & K & H & I & A & A & G & Y & L & Q & G & L & P & P\end{array}$ gcggagcatcaggactccgaga tggcgaaggtgg tggcgccggcggagtca cggaaggcc $\begin{array}{llllllllllllllllllll}A & E & H & Q & D & S & E & M & A & K & V & V & A & P & A & E & S & R & K & A\end{array}$ gtcgaaaccttcggccagcgcacatctatctaccgcggcgtcaccaggcatcgatggacg $\begin{array}{llllllllllllllllllll}V & E & I & F & G & Q & R & T & S & I & Y & R & G & V & I & R & H & R & W & T\end{array}$ ggtcgatacgagg cg ca cct ctgggacaacagctgccgccgggagggt cagagccggaag $\begin{array}{llllllllllllllllllll}G & R & Y & E & A & H & L & W & D & N & S & C & R & R & E & G & Q & S & R & K\end{array}$ ggaaggcaagtctatct tgg tggatacgataaggaggagaaggcggcgagggct tacgat

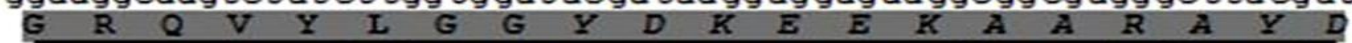

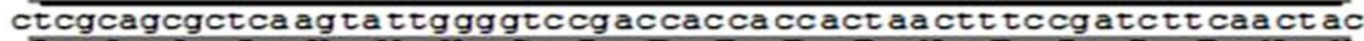

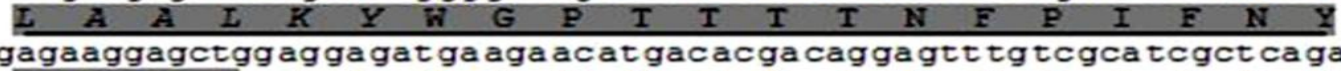

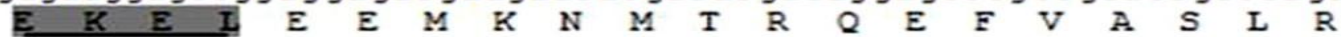
aggaagagctctgggttctccagaggcgcatcga tctataggggagtcaccagacaccat $R \quad K \quad S \quad S \quad G \quad F \quad S \quad R \quad G \quad A \quad S \quad I \quad Y \quad R \quad G \quad V \quad T \quad R \quad H \quad H$ caacatggccggtggca agctagaa $\tau \tau g g a a g g g t a g c a g g c a a c a a a g a t c t \tau t a t c t \tau$

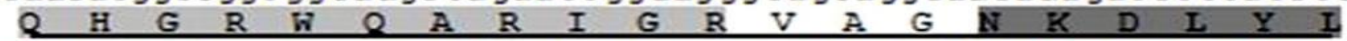
ggaacct $\tau$ agca cgcagga agaggca gcggaggccta $\operatorname{gaca} \tau \tau g c a g c a a t \tau a a g t \tau \tau$

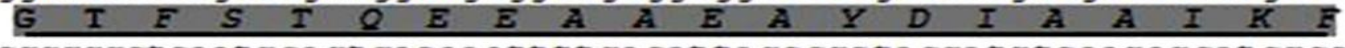

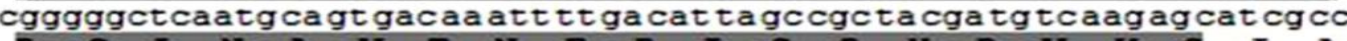

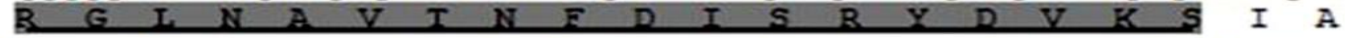
aacagcaacct $c c c a t \tau g g g g g g a \tau g a c a g g c c g g c c c t c c a a g g c c a c a g a a t c \tau t c g$ $\begin{array}{llllllllllllllllllll}N & S & N & L & P & I & G & G & M & T & G & R & P & S & K & A & I & E & S & S\end{array}$ ccatcatcctcatctgacgccatgactgtggaagccaagcagctgt tggacggccgggat

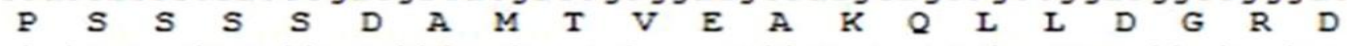
ctctcggcctcact $t g g g t \tau \tau g c t g c a c t c c c c a t \tau a a g c a c g a t c a g g a c t \tau c t g g t c c$

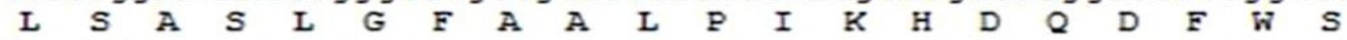

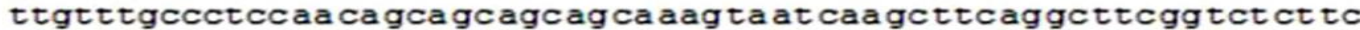

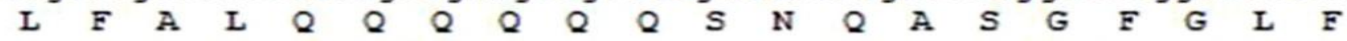
tcctctggtgtgactgtggact $\tau c t c c a c a g c t \tau c t a a t g g t g t \tau a \tau a a g c c a a g g g t g t$ $S \quad S \quad G \quad V \quad T \quad V \quad D \quad F \quad S \quad I \quad A \quad S \quad N \quad G \quad V \quad I \quad S \quad Q \quad G \quad C$ ggggggagcct $t g$ tg tggaa cggtggtgt tggagaacagcagcaggagcaa tcactgaac

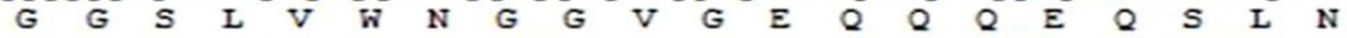
aatagttgctcttctatcccatatgcaacacctattgcatt tggagggaat tacgagggc

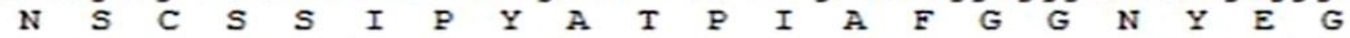
tccagctatgtggggagctggg tca caccaccaccctct tactaccacgaagctgccaag

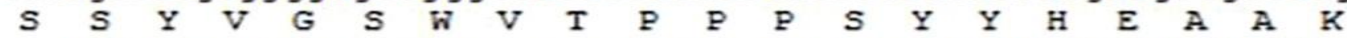
cccaltgtggcat $\tau c t \tau \tau c a g a c a c c c a t c t \tau \tau g g a a t g g a a t g a T A T G G A T G G G I G G G A$ $\begin{array}{lllllllllllllll}P & N & V & A & F & F & Q & T & P & I & F & G & M & E & -\end{array}$

AGGIGAGAGGAGA ICACACI IGCIT GAAGAGAAAGAGAGICAAAAGIGAGAGAGACCATG GGAGGIGATGCCAACIGACCACACI CACAAACATGAAGAAGGGAAGGAGAACAGAGGGAG GACTGACAAGAAGGCTA.ACAAGATATCAAAAGITIT GCTCATGGTCATGCGCCCAACT TC TITAACTITITGGIT TICTI ITCAT GACATGATICTATATIGICATCATCATCATCAGIG TAATGGAAACAAGAACCCTI ITGIA_AAAAAAAAAAAAAAAAAAAAAAAAAAA

Figure 1. cDNA sequence of coconut AINTEGUMENTA like homologue gene (CnANT). The nucleotide sequence and the putative protein sequences are shown. Two conserved AP2 domains are underlined. 5' and 3' UTRs are shown along with cDNA sequence in upper case letters. Numbers given in the right hand side are only for the putative amino acid sequence. Amino acid residues that encode the highly conserved YRG elements (128 to 149 and 230 to 251 respectively) in AP2 repeat 1 domain and repeat 2 domain are highlighted in light grey and the two RAYD element encoding amino acid residues (161 to 204 in repeat 1 and residues from 255 to 298 in repeat 2) are highlighted in dark grey. The specific central core of 18 amino acids within the RAYD element in each AP2 domain is illustrated in italic letters. 


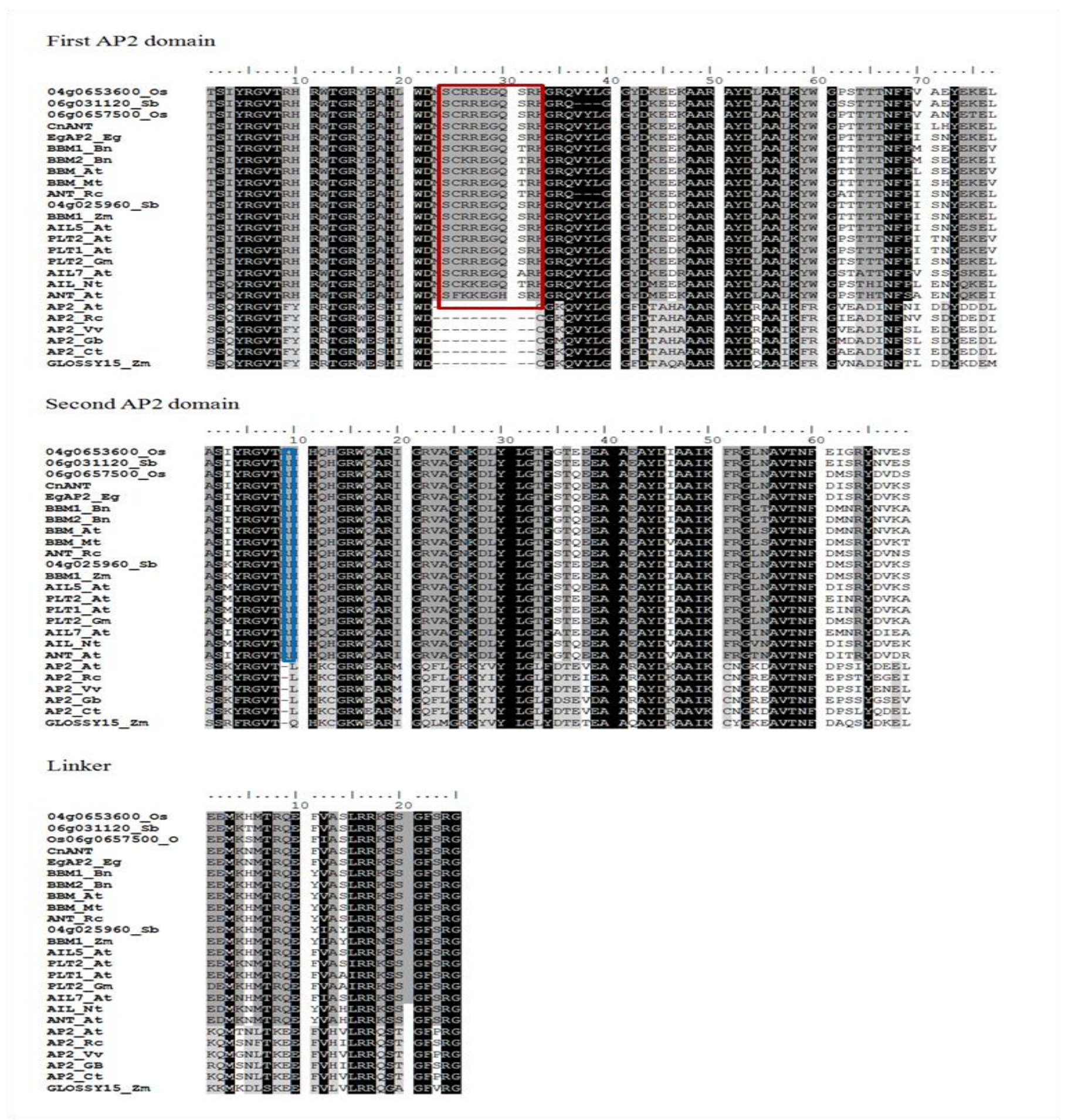

Figure 2. Comparison of CnANT protein sequence and related AP2 domain containing proteins. The amino acid sequences of two AP2 domains and the linker region connecting the two repeats of CnANT were aligned with the related AP2/EREB proteins. Black boxes indicate the amino acids that are identical in all members of the AP2 subfamily. Dark grey boxes shows the amino acids that are identical in all AIL sub group proteins. Amino acids that are identical in AP2 sub group are coloured in light grey. Note the 10 amino acid insertion in the AP2 repeat 1 (indicated by a red box) and one amino acid insertion in the AP2 repeat 2 (indicated by a blue box) which distinguish ANT genes from the rest of AP2 genes. 
observed for AP2 repeat 1 domain and repeat 2 domain, respectively. Two RAYD elements were identified from residues 161 to 204 in repeat 1 and residues from 255 to 298 in repeat 2 . Furthermore, the specific central core of 18 amino acids within the RAYD element which has been predicted as forming an alpha helix were also detected (residues 169-186 in repeat 1 and 263-280 in repeat 2; Figure 1) (Okamuro et al. 1997). The 10 amino acid insertion in the AP2 repeat 1 and one amino acid insertion in the AP2 repeat 2 which distinguish ANT genes from the rest of AP2 genes were identified in the CnANT sequence (Figure 2). This clearly showed that CnANT belongs to the ANT sub group (Nole-Wilson et al. 2005).

Furthermore, four conserved motifs identified (Kim et al. 2006) in the pre-domain region (EuANT 1, EuANT 2, EuANT 3 and EuANT 4) which are specified for the ANT sub group proteins were identified in the CnANT putative protein. Two AP2 domains and the linker region of the CnANT protein shows the highest similarity with EgAP2-1 (oil palm), ANT-like (rice), BBM, AIL5, AIL7, PLT1 and PLT2 (Arabidopsis), BBM (Brassica) and a number of recently identified hypothetical proteins available publicly. Amongst these genes, BBM (Boutilier et al. 2002), AIL5 (Tsuwamoto et al. 2010) Brassica BBM1 and BBM2 (Boutilier et al. 2002; Srinivasan et al. 2007), EgAP2-1 (Morcillo et al. 2007) have been characterized as embryogenesis related genes. Within the two AP2 repeat domains, these sequences share $~ 28 \%$ identity when consider both AP2 and ANT sub groups. However, the sequence identity is greatly increased $(>75 \%)$ when only ANT group proteins are considered. When examined carefully it was noted that pairs of genes share similarity within the entire AP2 domain sequences. Coconut and oil palm ANT protein sequences show $98 \%$ identity with each other in the conserved domain regions while CnANT shares more than $80 \%$ identity in the same region with other ANT subfamily proteins when a pair wise comparison was conducted (Figure 2). This observation emphasized that CnANT is strictly related with oil palm EgAP2-1 gene (Morcillo et al. 2007) and indicates its close relationship with the palm species sequence. In a recent study, Ouakfaoui et al. (2010) studied the conserved motifs of AP2 sub family outside of AP2 DNA binding domains and found ten sequence motifs of euANT lineage. Three of them identified at $\mathrm{N}$ terminal have been described by Kim et al (2006) previously. The euANT sub group was further categorized into BBM-like, PLT-like and AIL5like and oil palm EgAP2-1 was grouped as an AIL5-like gene (Ouakfaoui et al. 2010). Thus, similarity between oil palm EgAP2-1 and CnANT suggests CnANT to be grouped as AIL genes according to Ouakfaoui and colleagues classification and hence suggests that CnANT could play a role in embryogenesis as proposed for those orthologs.

The four cDNA libraries were sequenced using a GS FLX sequencer (454/Roche), resulting in a total of 979428 reads. These reads were assembled into 32621 putative unigenes and 155017 singletons. ESTs had an average length of $460 \mathrm{bp}$, and represented $223.7 \mathrm{Mb}$. Assembled sequences were functionally annotated with blast2go. Homology-based functional assignment for putative sequences was accomplished through BLASTX queries against non-redundant protein database with an e value cut-off of 1E-6 to identify AP2 family proteins in each library.

The highest number of APETALA family genes was found in the 9ME library which was represented by 16 contigs. The other three libraries 12ME, MDE and LEAF had 11, 12 and 10 contigs respectively which were encoded for AP2 family genes. As per the putative annotations made from BLASTX hits, most of them were of the ERF subfamily which has a single AP2 domain. Also there were contigs encoded for RAV subfamily genes (genes containing one AP2 domain and a second B3 domain) and AP2/ANT subfamily genes. Interestingly, CnANT gene which was described early in this paper could be identified in all embryo tissue libraries (Table 1; marked with an asterisk). These contigs returned the highest significant similarity [Evalue ranged from $1.04 \mathrm{E}-33$ (9ME \& MDE) to $1.66 \mathrm{E}-166$ (12ME)] with the oil palm Aintegumenta-like gene; 
Table 1. Identification of AP2 family genes and CnANT in LEAF, 9ME, 12ME and MDE Library ESTs

\begin{tabular}{|c|c|c|c|c|c|}
\hline Contig name & $\begin{array}{l}\text { No of } \\
\text { ESTs }\end{array}$ & Putative identity & Species & GI number & E value \\
\hline \multicolumn{6}{|l|}{ 9ME } \\
\hline contig00041 & 6 & $\begin{array}{l}\text { AP2/ERF domain containing } \\
\text { protein }\end{array}$ & Oryza sativa & 25548125 & $3.22 \mathrm{E}-16$ \\
\hline contig00367 & 11 & AP2 domain containing protein & Vitis vinifera & 297743010 & 7.17E-15 \\
\hline contig01025 & 33 & $\begin{array}{l}\text { AP2/ERF domain containing } \\
\text { protein }\end{array}$ & Populus trichocarpa & 224075453 & $7.66 \mathrm{E}-28$ \\
\hline contig01586 & 5 & AP2 domain containing protein & Oryza sativa & 25603736 & 3.00E-09 \\
\hline contig01721 & 8 & AP2/ERF transcription factor & Lycoris logituba & 295913651 & $2.36 \mathrm{E}-09$ \\
\hline contig02544 & 3 & RAV & Nicotiana tabacum & 194475604 & $2.45 \mathrm{E}-46$ \\
\hline contig02679 & 16 & AP2/ERF factor & Actinidia deliciosa & 300079016 & $1.95 \mathrm{E}-21$ \\
\hline contig03137 & 4 & AP2/ERF FACTOR & Populus trichocarpa & 224128256 & $1.00 \mathrm{E}-07$ \\
\hline contig03897 & 8 & AP2/ERF FACTOR GENE & Lycoris logituba & 295913454 & $1.79 \mathrm{E}-25$ \\
\hline contig04205 & 2 & AINTEGUMENTA Protein & Ricinus communis & 255547490 & $2.22 \mathrm{E}-44$ \\
\hline contig04757 & 2 & ERF3 Transcription factor & Vitis vinifera & 22544716 & $3.57 \mathrm{E}-11$ \\
\hline contig05190 & 63 & ERF transcription factor 3 & Vitis pseudoreticulata & 289466347 & $1.44 \mathrm{E}-60$ \\
\hline contig05434 & 19 & AP2 protein* & Elaeis guineensis & 56567285 & $1.05 \mathrm{E}-33$ \\
\hline contig05623 & 19 & APETALA2 & Hyacinthus orientalis & 5360996 & $2.53 \mathrm{E}-35$ \\
\hline contig05624 & 33 & AP2/ERF factor gene & Populus trichocarpa & 295913424 & $6.92 \mathrm{E}-21$ \\
\hline contig05812 & 9 & APETALA2-LIKE & Pisum sativum & 13173164 & $1.87 \mathrm{E}-30$ \\
\hline \multicolumn{6}{|l|}{ 12ME } \\
\hline contig00041 & 211 & AP2 protein* & Elaeis guineensis & 56567285 & $1.66 \mathrm{E}-166$ \\
\hline contig00486 & 25 & ERF factor 2 & Prunus salicina & 222427675 & $2.91 \mathrm{E}-68$ \\
\hline contig00853 & 3 & EREB-like protein & Oryza sativa & 25559179 & $1.01 \mathrm{E}-12$ \\
\hline contig01069 & 31 & ERF transcription factor 3 & Vitis pseudoreticulata & 289466347 & $5.10 \mathrm{E}-62$ \\
\hline contig02415 & 7 & AP2/ERF transcription factor & Lycoris longituba & 295913651 & $4.90 \mathrm{E}-24$ \\
\hline contig03252 & 6 & $\begin{array}{l}\text { AP2/ERF domain containing } \\
\text { protein }\end{array}$ & Populus trichocarpa & 295913424 & $6.29 \mathrm{E}-10$ \\
\hline contig03842 & & ethylene responsive protein & Zea mays & 226497004 & 8.57E-12 \\
\hline contig04354 & 20 & Aintegumenta like 1 & Vitis vinifera & 47832538 & $1.09 \mathrm{E}-41$ \\
\hline contig04480 & 5 & APETALA2-LIKE & Pisum sativum & 13173164 & $2.11 \mathrm{E}-34$ \\
\hline contig04711 & 14 & AP2/ERF factor & Oryza sativa & 25548125 & $1.18 \mathrm{E}-17$ \\
\hline contig04898 & 45 & AP2/ERF FACTOR & Populus trichocarpa & 224075453 & $7.81 \mathrm{E}-28$ \\
\hline \multicolumn{6}{|l|}{ MDE } \\
\hline contig00907 & 5 & RAV & Nicotiana tabacum & 194475604 & $1.30 \mathrm{E}-71$ \\
\hline contig01217 & 7 & APETALA2 & Hyacinthus orientalis & 5360996 & $1.47 \mathrm{E}-35$ \\
\hline contig01626 & 28 & ERF transcription factor 3 & Vitis pseudoreticulata & 289466347 & $1.55 \mathrm{E}-33$ \\
\hline contig02007 & 34 & AP2 protein* & Elaeis guineensis & 56567285 & $1.04 \mathrm{E}-33$ \\
\hline contig02444 & 14 & AP2/EREBP transcription factor & Vitis vinifera & 297742325 & $7.15 \mathrm{E}-17$ \\
\hline contig03285 & 8 & APETALA2 protein & Oryza sativa & 222629673 & $2.82 \mathrm{E}-27$ \\
\hline
\end{tabular}




\begin{tabular}{llllll}
\hline contig03381 & 7 & AP2/ERF factor & Oryza sativa & 115463423 & $1.23 \mathrm{E}-23$ \\
contig05046 & 4 & AP2/ERF factor & Actinidia deliciosa & 300079018 & $9.61 \mathrm{E}-11$ \\
contig07109 & 4 & AP2/ERF transcription factor & Lycoris logituba & 295913424 & $1.14 \mathrm{E}-19$ \\
contig08165 & 18 & $\begin{array}{l}\text { AP2 domain DRE binding } \\
\text { protein }\end{array}$ & Cymbidium insigne & 49980678 & $4.29 \mathrm{E}-11$ \\
& & AP2/ERF transcription factor & Lycoris logituba & 295913424 & $4.96 \mathrm{E}-15$ \\
contig08519 & 2 & Vitis vinifera & 297746184 & $4.98 \mathrm{E}-39$ \\
contig09160 & 27 & APETALA protein & & & \\
LEAF & & & Hyacinthus orientalis & 5360996 & $6.03 \mathrm{E}-27$ \\
contig00169 & 4 & APETALA2 & Arabidopsis thaliana & 15221435 & $1.62 \mathrm{E}-09$ \\
contig04147 & 17 & AP2 domain containing & Actinidia deliciosa & 300079016 & $5.34 \mathrm{E}-31$ \\
& & transcription factor & Hyacinthus orientalis & 5360996 & $3.78 \mathrm{E}-21$ \\
contig04233 & 4 & AP2/ERF factor 10 & Triticum aestivum & 82780772 & $7.41 \mathrm{E}-25$ \\
contig08025 & 3 & APETALA2 & Vitis vinifera & 225463950 & $1.36 \mathrm{E}-10$ \\
contig08521 & 3 & Aintegumenta protein & Ricinus communis & 255578779 & $3.35 \mathrm{E}-40$ \\
contig08923 & 4 & AP2/EREBP transcription factor \\
contig09150 & 15 & Aintegumenta protein & Vitis vinifera & 225435173 & $1.03 \mathrm{E}-45$ \\
contig09168 & 33 & AP2 domain containing protein & Hyacinthus orientalis & 5360996 & $7.56 \mathrm{E}-38$ \\
contig09396 & 33 & APETALA2 & Nicotiana tabacum & 30961941 & $2.07 \mathrm{E}-12$ \\
contig11376 & 29 & ERF factor 3 &
\end{tabular}

*similar contigs for CnANT gene showing BLASTX sequence similarity with oil palm AINTEGUMENTA-like gene $($ EgAP2-1)

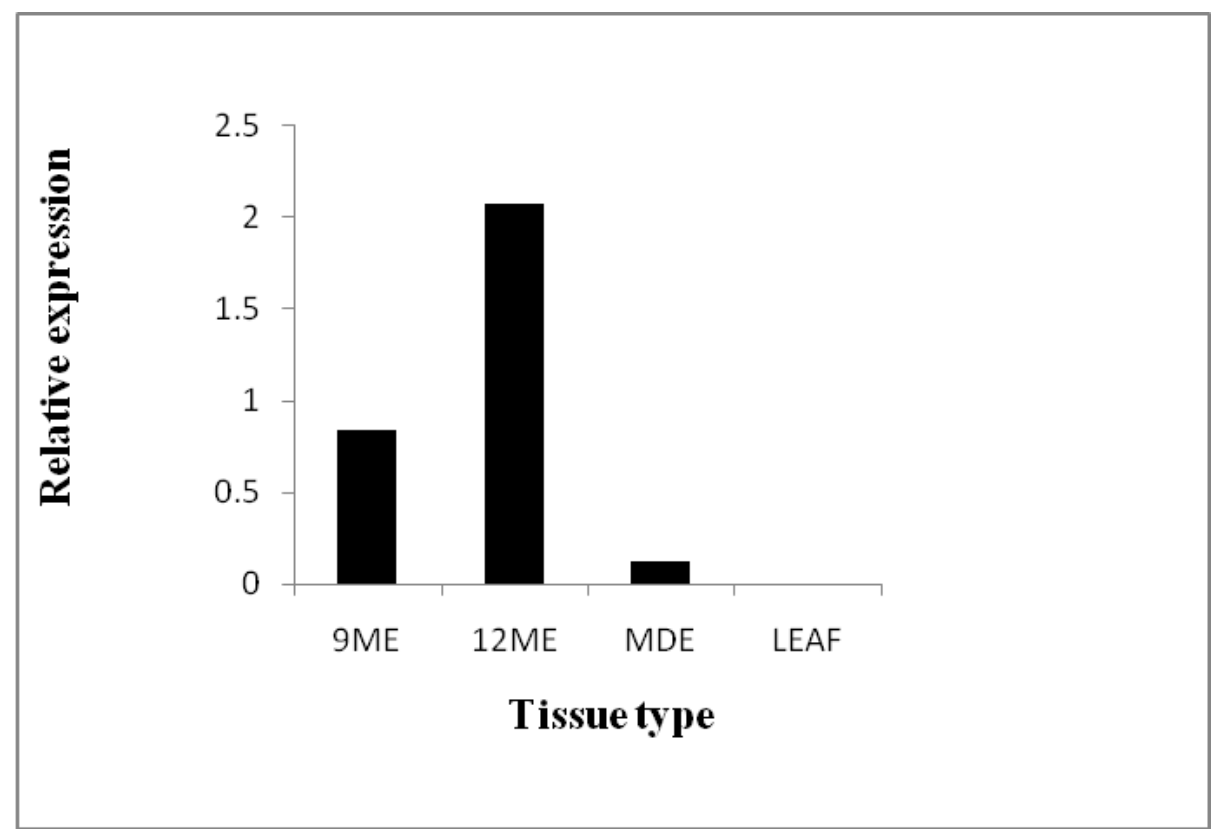

Figure 3. Relative expression levels of CnANT accumulation in the four different tissue types determined by RT-qPCR analysis. CnANT transcripts were compared relative to the elongation factor gene. LEAF: leaf, 9ME: embryo, 9 month after pollination, 12ME: embryo, 12 month after pollination MDE: microspore derived embryo 
EgAP2-1 (Morcillo et al. 2007) when subject to a BLASTX homology search. The EST abundance of this gene was high in the $12 \mathrm{ME}$ library. Even though the abundance was not as high in the 12ME library, a considerable number of ESTs was encoded by the contigs in $9 \mathrm{ME}$ and MDE. In 9ME, the contig was present 19 times while in MDE it appeared 34 times. However no transcripts encoding the CnANT gene were found in LEAF library. These observations are comparable with the results obtained from the quantitative real time PCR where the highest relative expression was observed in $12 \mathrm{ME}$ while LEAF tissues showed negligible relative expression (Figure 3). Furthermore, the comparison of putative gene annotations, species and GI values of the contigs in different libraries revealed that a few more genes from the AP2 family are common to embryo tissue libraries (Table 1).

The present study provides evidence that CnANT is strongly induced in late embryogenesis and plays a role during zygotic embryo maturation phase. First, a qPCR experiment showed higher relative expression at the most mature stage of zygotic embryo (12 months after pollination). Secondly, global transcriptome analysis carried out using different stages of embryo maturity showed a higher accumulation of CnANT transcripts in the 12ME library compared to the 9ME library and the LEAF library based on the BLASTX analysis (sequence cut-off $1.0 \mathrm{e}^{-6}$ ). The expression data and global transcriptome data are therefore consistent across the embryo maturity stage. Higher expression of AIL5 and BBM genes in later stages of embryo development has been reported previously (Boutilier et al. 2002; Morcillo et al. 2007; Tsuwamoto et al. 2010). Unlike in BBM which was expressed in stages as early as the globular stage, AIL gene expression has been analysed after laser capture microdissection and in situ hybridization and shown to occur only in embryos older than the heart stage (Casson et al. 2005; Tsuwamoto et al. 2010).

Based on the results, presence of AIL gene in coconut is reported and findings supports the fact that this gene is highly expressed in maturing stages of embryo. CnANT could be used as embryogenesis marker, since its expression changed with progression of embryo development. These findings may offer a valuable contribution to the evaluation of embryogenic culture responses in coconut.

\section{References}

Alagna F., D'Agostino N., Torchia L., Servili M., Rao R., Pietrella M., Giuliano G., Chiusano M.L., Baldoni L. and Perrotta G (2009) Comparative 454 pyrosequencing of transcripts from two olive genotypes during fruit development. BMC Genomics 10: 399

Banno H., Ikeda Y., Niu Q-W. and Chua N-H. (2001) Overespression of Arabidopsis ESRl induces initiation of shoot regeneration. Plant Cell 13: 2609-2618

Barakat A., DiLoreto D.S., Zhang Y., Smith C., Baier K., Powell W.A., Wheeler N., Sederoff R. and Carlson J.E. (2009) Comparison of the transcriptomes of American chestnut (Castanea dentata) and Chinese chestnut (Castanea mollissima) in response to the chestnut blight infection. BMC Plant Biol 9: 51

Boutilier K., Offringa R., Sharma V.K., Kieft H., Ouellet T., Zhang L., Hattori J., Liu C-M., van Lammeren A.A.M., Miki B.L.A., Clusters J.B.M. and van Lookeren Campagne M.M. (2002) Ectopic expression of $B A B Y$ BOOM triggers a conversion from vegetative to embryonic growth. Plant Cell 14: 1737-1749

Branton R.L. and Blake J. (1983) Development of organized structures in callus derived from explants of Cocos nucifera L. Ann Bot 52:673-678

Brautigam A. and Gowik U. (2010) What can next generation sequencing do for you? Next generation sequencing as a valuable tool in plant research. Plant Biol (Stuttg) 12(6):831-841

Cairney J. and Pullman G.S. (2007) The cellular and molecular biology of conifer 
embryogenesis. New Phytologist 176: 511-536

Casson S., Spencer M., Walker K. and Lindsey K. (2005) Laser capture microdissection for the analysis of gene expression during embryogenesis of Arabidopsis. Plant J 42: $111-123$

Fernando S.C. and Gamage C.K. (2000) Abscisic acid induced somatic embryogenesis in immature embryo explants of coconut (Cocos nucifera L.). Plant Sci. 151: 193-198

George E.F. and Sherrington P.D. (1984) Plant Propagation by Tissue Culture-Handbook and Directory of Commercial Laboratories. Exegetics Ltd, Edington, UK

Graham I.A., Besser K., Blumer S., Branigan C.A., Czechowski T., Elias L., Guterman I., Harvey D., Isaac P.G., Khan A.M., Larson T.R., Li Y., Pawson T., Penfield T., Rae A.M., Rathbone D.A., Reid S., Ross J., Smallwood M.F., Segura V., Townsend T., Vyas D., Winzer T. and Bowles D. (2010) The genetic map of Artemisia annua L. identifies loci affecting yield of the antimalarial drug artemisinin. Science 327:328-331

Hornung R. (1995) Micropropagation of Cocos nucifera (L). from plumular tissues excised from mature zygotic embryos. Plant Rech Dev 2: 38-41

Karunaratne S. and Periyapperuma K. (1989) Culture of immature embryos of coconut (Cocos nucifera L.): callus proliferation and somatic embryogenesis. Plant Sci 62: 247-253

Kim S., Soltis P.M., Wall K. and Soltis D.E. (2006) Phylogeny and domain evolution in the APETALA2-like gene family. $\mathrm{Mol}$ Biol Evol 23: 107-120

Li Y., Luo H.M., Sun C., Song J.Y., Sun Y.Z., Wu Q., Wang N., Yao H., Steinmetz A. and Chen S.L. (2010) EST analysis reveals putative genes involved in glycyrrhizin biosynthesis. BMC Genome 11:268
Luo H., Li Y., Sun C., Wu Q., Song J., Sun Y., Steinmetz A. and Chen S. (2010) Comparison of 454-ESTs from Huperzia serrata and Phlegmariurus carinatus reveals putative genes involved in lycopodium alkaloid biosynthesis and developmental regulation. BMC Plant Biol 10:209

Morcillo F., Gallard A., Pillot M., Jouannic S., Aberlenc-Bertossi F., Collin M., Verdeil JL. and Tregear J.W. (2007) EgAP2-1, an AINTEGUMENTA-like (AIL) gene expressed in meristematic and proliferating tissues of embryos in oil palm. Planta 226: 1353-1362

Morozova O., Hirst M. and Marra M.A. (2009) Applications of new sequencing technologies for transcriptome analysis. Annu Rev Genomics Hum Genet 10:135151

Nole-Wilson S., Tranby T.L. and Kreizek A. (2005) AINTEGUMENTA-like (AIL) genes are expressed in young tissues and may specify meristematic or divisioncompetent states. Plant Mol Biol 57: 613628

Novaes E., Drost D.R., Farmerie W.G., Pappas G.J., Grattapaglia D., Sederoff R.R. and Kirst M. (2008) High-throughput gene and SNP discovery in Eucalyptus grandis, an uncharacterized genome. BMC Genomics 9: 312

Okamuro J.K., Caster B., Villarroel R., VanMontagu M. and Jofuku K.D. (1997) The AP2 domain of APETALA2 defines a large new family of DNA binding proteins in Arabidopsis. Proc Natl Acad Sci USA 94: 7076-7081

Olsvik P.A., Lie K.K., Jordal A.E., Nilsen T.O. and Hordvik I. (2005) Evaluation of potential reference genes in real time RTPCR studies of Atlantic salmon. BMC Mol Biol 6: 21

Ouakfaoui S.E., Schnell J., Abdeen A., Colville A., Labbe H., Han S., Baum B., Laberge S. and Miki B. (2010) Control of somatic 
embryogenesis and embryo development by AP2 transcription factors. Plant $\mathrm{Mol}$ Biol 74: 313-326

Palovaara J., Hallberg H., Stasolla C. and Hakman I. (2010) Comparative expression pattern analysis of WUSCHEL related homeobox 2 (WOX2) and WOX89 in developing seeds and somatic embryos of the gymnosperm Picea abies. New Phytologist 188: 122-135

Perera P.I.P., Hocher V., Verdeil J-L., Bandupriya H.D.D., Yakandawala D.M.Y., Weerakoon L.K. (2008) Androgenic potential of coconut (Cocos nucifera L.). Plant Cell Tiss Organ Cul 92: 293-302

Perera P.I.P., Hocher V., Verdeil J-L., Doulbeau S., Yakandawala D.M.Y., Weerakoon L.K. (2007) Unfertilized ovary: a novel explant for coconut (Cocos nucifera L.) somatic embryogenesis. Plant Cell Rep 26: 21-28

Srinivasan C., Liu Z., Heidmann I. and Supena E.D.J. (2007) Heterologous expression of the $B A B Y$ BOOM AP2/ERF transcription factor enhances the regeneration capacity of tobacco (Nicotiana tabacum L.). Planta 225: $341-351$

Tsuwamoto R., Yokoi S. and Takahata Y. (2010) Arabidopsis EMBRYOMAKER encoding an AP2 domain transcription factor plays a key role in develpomental change from vegetative to embryonic phase. Plant Mol Biol 73: 481-492

Verdeil J-L., Huet C., Grosdemange F. and Buffard-Morel J. (1994) Plant regeneration from cultured immature inflorescence of coconut (Cocos nucifera L.): evidence for somatic embryogenesis. Plant Cell Rep 13: 218-221

Wang W., Wang Y., Zhang Q., Qi Y. and Guo D. (2009) Global characterization of Artemisia annua glandular trichome transcriptome using 454 pyrosequencing. BMC Genom 10:465 